\title{
Light- and electron-microscope description of Kudoa paralichthys n. sp. (Myxozoa, Myxosporea) from the brain of cultured olive flounder Paralichthys olivaceus in Korea
}

\author{
Jae Bum Cho, Ki Hong Kim* \\ Department of Aquatic Life Medicine, Pukyong National University, Pusan 608-737, South Korea
}

\begin{abstract}
A new Myxosporea, Kudoa paralichthys n. sp., is described from the brain of cultured olive flounder Paralichthys olivaceus in South Korea. Mature spores were quadrate in apical view, measuring $5.19 \pm 0.54 \mu \mathrm{m}$ in length, $8.23 \pm 0.50 \mu \mathrm{m}$ in width, and $6.87 \pm 0.45 \mu \mathrm{m}$ in thickness. Four valves were equal in size, each with 1 polar capsule. Polar capsules were pyriform in shape, measuring $2.2 \pm 0.22 \mu \mathrm{m}$ in length and $1.2 \pm 0.14 \mu \mathrm{m}$ in breadth. The sporoplasm consisted of a larger outer cell completely surrounding a smaller inner one, and had cytoplasmic projections. The junctions of shell valves were L-shaped. The sutural planes converged at the anterior ends of the spores and were associated with 4 small apex prominences in the central meeting point of the spores.
\end{abstract}

KEY WORDS: Myxosporea $\cdot$ Kudoa paralichthys n. sp. · Brain tissue $\cdot$ Olive flounder

\section{INTRODUCTION}

Species of the genus Kudoa Meglitsch, 1947 are myxosporean parasites with 4 valves, each of which contains a polar capsule, and 46 identified species are recorded within the genus (Moran et al. 1999, Pampoulie et al. 1999, Swearer \& Robertson 1999). Most Kudoa species are seen in the skeletal musculature and have been associated with post-mortem myoliquefaction in commercially important marine fishes (Moran et al. 1999). The few remaining species have been described from tissues that include the gills, brain, gall bladder, pericardial cavity and ovary (Lom \& Dyková 1992, Swearer \& Robertson 1999).

Three species, including 1 unidentified species, of Kudoa-K. cerebralis, K. tetraspora and Kudoa sp.have been reported from the brain of marine and brackish fishes (Paperna \& Zwerner 1974, Narasimhamurti \& Kalavati 1979, Langdon 1990). In the present study, we found the new species $K$. paralichthys from the brain of cultured olive flounder Paralichthys olivaceus, and described its spore morphology and ultrastructural characteristics.

\section{MATERIALS AND METHODS}

Juvenile olive flounder Paralichthys olivaceus $(25 \mathrm{~cm}$ average body length) were taken from commercial farms in South Korea. Squash preparations of fresh tissues from brain were examined by light microscope. Descriptions and measurements of spores were performed according to the guidelines for species description of myxosporeans by Lom \& Arthur (1989), and by using a light microscope equipped with an ocular micrometer and image analysis software (ImageTool ver 2.0, UTHSCSA). Mean and standard deviations of each spore characteristic were obtained from 50 fresh mature spores.

For the transmission electron microscopy study, portions of the brain tissue were fixed in $2 \% \mathrm{v} / \mathrm{v}$ glutaraldehyde in $0.1 \mathrm{M}$ cacodylate buffer $(\mathrm{pH} 7.2)$ at $4^{\circ} \mathrm{C}$ overnight, and postfixed in $1 \% \mathrm{w} / \mathrm{v}$ cacodylic $\mathrm{OsO}_{4}$ for $2 \mathrm{~h}$. The specimens were dehydrated, embedded in epoxy resin (Spurr) and ultrathinsectioned, stained with uranyl acetate and lead citrate, and examined by a JEOL JEM1200 transmission electron microscope. 


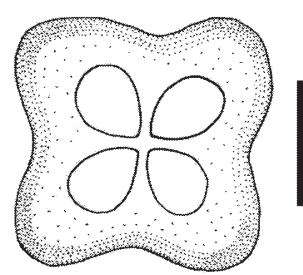

(A)
(B)

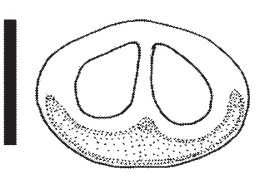

Fig. 1. Kudoa paralichthys n. sp. Line drawing from the brain of olive flounder Paralichthys olivaceus. (A) Apical view; (B) lateral view. Scale bar $=3.5 \mu \mathrm{m}$

\section{RESULTS}

\section{Spore characteristics of Kudoa paralichthys n. sp.}

Mature spores (Figs. 1 \& 2) were a quadrate shape, with shallow constrictions between the valves in apical view and broadly oval in lateral view, measuring $5.19 \pm$ $0.54 \mu \mathrm{m}$ in length, $8.23 \pm 0.50 \mu \mathrm{m}$ in width, and $6.87 \pm$ $0.45 \mu \mathrm{m}$ in thickness. Four valves were equal in size, each with 1 polar capsule. Polar capsules were pyriform and equal in size, each measuring $2.2 \pm 0.22 \mu \mathrm{m}$ in length, $1.2 \pm 0.14 \mu \mathrm{m}$ in breadth, and containing a polar filament.

Specific details are as follows. Host: olive flounder Paralichthys olivaceus; locality: Namhae, Kyongsangnam-Do, South Korea; site of infection: brain; specimens deposited: Laboratory of Fish and Shellfish Parasitology, Department of Aquatic Life Medicine, Pukyong National University, South Korea. Accession number PKNU-Pmy-0105; etymology: the specific name refers to the genus name of the host.

\section{Transmission electron microscopy}

The earliest stage observed was a sporoblast containing voluminous valvogenic cells and a clearly delineated sporoplasm (Fig. 3A). The sporoplasm consisted of a larger outer cell completely surrounding a smaller inner one, and had cytoplasmic projections (Fig. 3A). Valvogenic cells became elongated and flattened as the development of capsulogenic cells progressed (Fig. 3B). A bulbous capsular primordium had an electron-dense core, and was closely associated with the external tubule (Fig. 3B,C). The disappearance of the external tubule coincided with the presence of the coiled internal polar filament. Capsulogenic cells had distended cisternae of rough endoplasmic reticulum (ER) and numerous mitochondria (Fig. 3D). The sutures between the 4 valvogenic cells were L-shaped in both longitudinal and cross- sectioned specimens (Fig. 4A-C). The sutural planes converged at the anterior ends of the spores and were associated with 4 small apex prominences in the central meeting point of the spores (Fig. 4D).

\section{DISCUSSION}

Based on spore dimensions, host species, site of infection, and geographic location, the present myxosporean is a new species of the genus Kudoa that we describe as $K$. paralichthys. The only 3 Kudoa species found in the brain tissue of fish in past studies were $K$. cerebralis from the striped bass Morone saxatilis (Paperna \& Zwerner 1974), K. tetraspora from the mullet Mugil cephalus (Narasimhamurti \& Kalavati 1979), and Kudoa sp. from the barramundi perch Lates calcarifer (Langdon 1990). K. paralichthys n. sp. is clearly distinguished from K. tetraspora and Kudoa sp. by the smaller spore and polar capsule sizes (Table 1). Although the spore dimensions of $K$. paralichthys are similar to those of $K$. cerebralis, it can be distinguished from $K$. cerebralis by the difference in ratio between length and width of polar capsules. The latter species clearly has longer polar capsules compared to $K$. paralichthys.

In the present ultrastructural study, Kudoa paralichthys had 2 uninucleated sporoplasms, represented by one cell enveloping the other completely. This doublet cell structure of sporoplasm has also been reported in other Kudoa species by electron microscopical observations (Stehr 1986, Lom \& Dyková 1988, Dyková et al. 1994). The processes extended from the sporoplasm of $K$. paralichthys have not been observed in any other Kudoa species. However, we could not know their exact biological meanings. The presence of an external tubule in early developmental stages of capsulogenic cells, and the disappearance of the

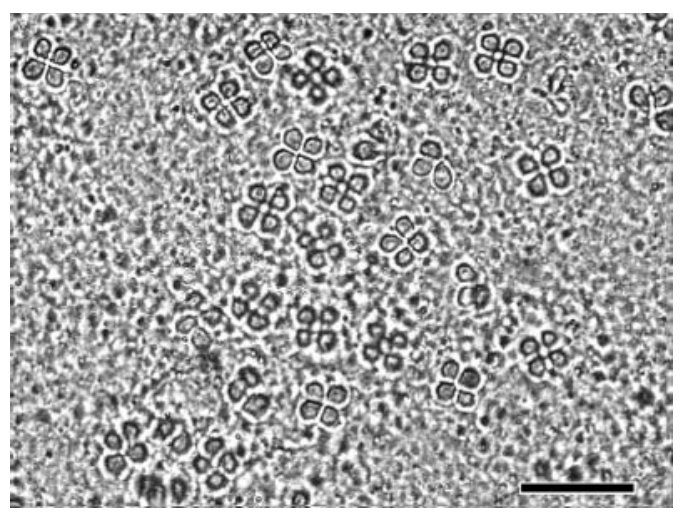

Fig. 2. Kudoa paralichthys n. sp. Fresh smear of mature spores from the brain of olive flounder Paralichthys olivaceus. Scale bar $=12.7 \mu \mathrm{m}$ 


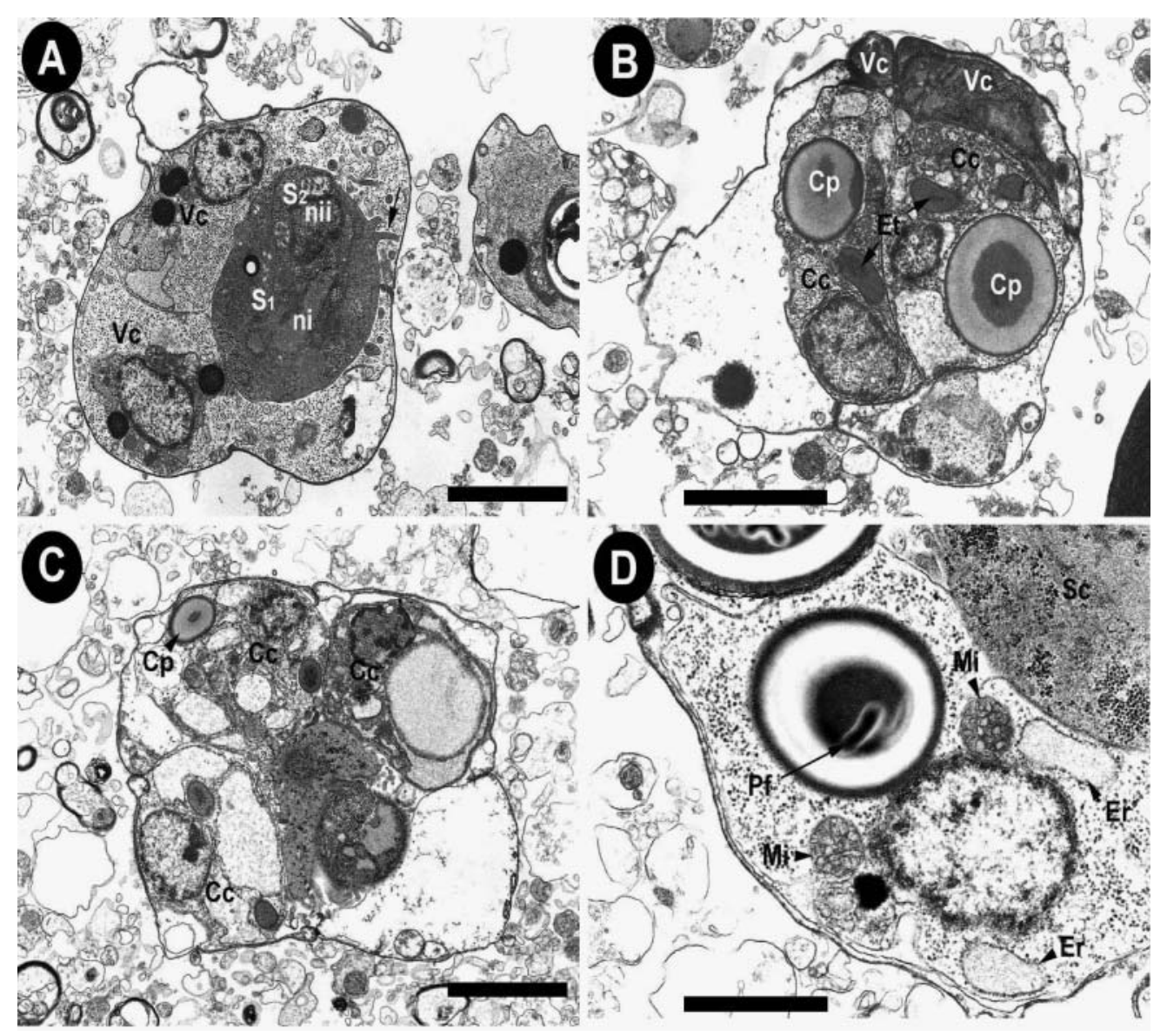

Fig. 3. Kudoa paralichthys n. sp. Ultrastructure of developmental stages. (A) Sporoblast with 2 uninucleated sporoplasms ( $\mathrm{S}_{1}$ and $\mathrm{S}_{2}$ ), enveloped by voluminous valvogenic cells (Vc). Arrow indicates cytoplasmic processes. $\mathrm{S}_{1}$ : outer sporoplasm; $\mathrm{S}_{2}$ : inner sporoplasm; ni: nucleus of outer sporoplasm; nii: nucleus of inner sporoplasm. Scale bar $=1 \mu \mathrm{m}$. (B) Two capsulogenic cells (Cc) surrounded by 2 valvogenic cells $(\mathrm{Vc})$. Capsulogenic cells containing capsular primordia $(\mathrm{Cp})$ and external tubule $(\mathrm{Et})$. Scale bar $=$ $1 \mu \mathrm{m}$. (C) Cross section through 4 capsulogenic cells with capsular primordia. Scale bar $=1 \mu \mathrm{m}$. (D) Capsulogenic cell containing various organelles near the nucleus. Er: endothelial reticulum; Mi: mitochondria; Pf: polar filament. Scale bar $=1 \mu \mathrm{m}$

Table. 1. Kudoa paralichthys n. sp. Comparisons of morphological characteristics with other Kudoa species infecting in the brain tissue of fish host. PC: polar capsule

\begin{tabular}{|c|c|c|c|c|}
\hline Species & Kudoa cerebralis & Kudoa tetraspora & Kudoa sp. & Kudoa paralichthys n. sp. \\
\hline Host & Morone saxatilis & Mugil cephalus & Lates calcarifer & Paralichthys olivaceus \\
\hline Infection site & Brain & Brain, optic lobes & Brain & Brain \\
\hline Locality & $\begin{array}{c}\text { Chesapeake Bay, } \\
\text { USA }\end{array}$ & India & $\begin{array}{c}\text { North Queensland, } \\
\text { Australia }\end{array}$ & $\begin{array}{l}\text { Namhae, } \\
\text { South Korea }\end{array}$ \\
\hline Spore shape in apical view & $N_{N} \quad$ Quadrate & Quadrate & Quadrate & Quadrate \\
\hline Spore length & $5.5(4.8-5.8)$ & & $6.5-7.0$ & $5.19(4.49-5.97)$ \\
\hline Spore width & $7.0(4.8-8.6)$ & 9.0 & $9.0-10.0$ & $8.23(7.4-8.89)$ \\
\hline Spore thickness & $6.4(5.8-7.2)$ & 9.0 & & $6.87(6.29-7.71)$ \\
\hline PCs shape & Pyriform & Elongate & Pyriform & Pyriform \\
\hline PCs length & $3.7(2.6-4.7)$ & 3.6 & $3.1-3.2$ & $2.2(1.87-2.74)$ \\
\hline PCs width & $1.5(1.0-1.8)$ & 2.0 & $2.0-2.3$ & $1.2(1-1.42)$ \\
\hline Valve-extensions & Absent & Absent & Absent & Absent \\
\hline Source & $\begin{array}{c}\text { Paperna \& Zwerner } \\
(1974)\end{array}$ & $\begin{array}{l}\text { Naraimhamurti \& } \\
\text { Kalavati (1979b) }\end{array}$ & $\begin{array}{l}\text { Langdon } \\
\text { (1990) }\end{array}$ & - \\
\hline
\end{tabular}



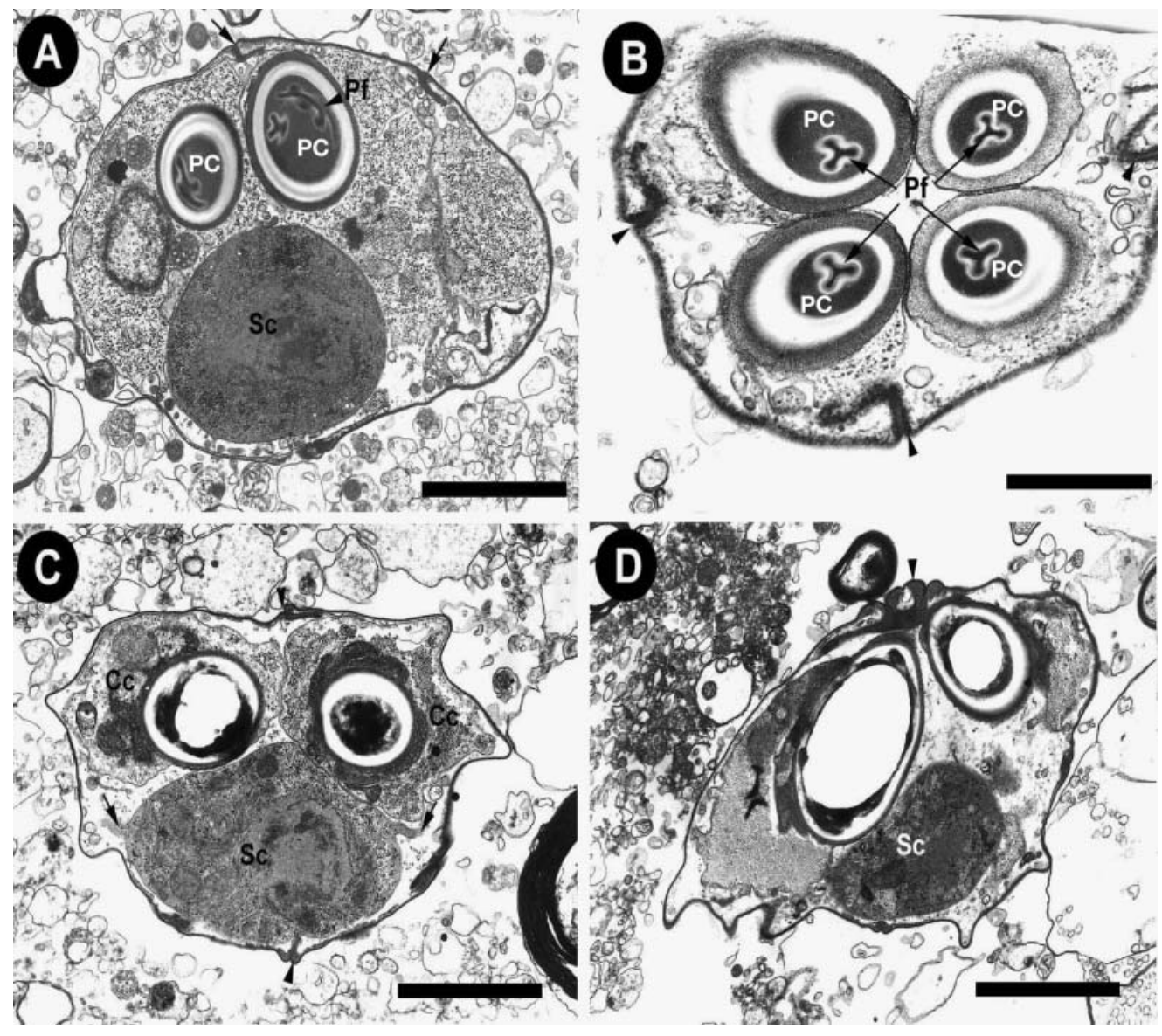

Fig. 4. Kudoa paralichthys n. sp. Ultrastructure of mature spore. (A) Longitudinal section through 2 polar capsules (PC) and sporoplasm (Sc). Polar capsule contains coiled polar filaments (Pf). Arrows indicate valvular suture. Scale bar = $1 \mu \mathrm{m}$. (B) Cross section through 4 polar capsules. Polar filament (Pf) within polar capsule (PC) and L-shaped valvular suture (arrowheads) are present in the spore. Scale bar $=1 \mu \mathrm{m}$. (C) Cytoplasmic extension (arrows) of sporoplasm. Arrowheads indicate valvular suture. Scale bar $=$ $1 \mu \mathrm{m}$. (D) Apex prominences (arrowhead) at the central meeting point of the spores. Sc: sporoplasmic cell. Scale bar $=1 \mu \mathrm{m}$

tubule according to the maturation of capsular primordium, were also found in other myxosporean species (Lom \& Dyková 1988, 1996, Sitja-Bobadilla \& Alvarez-Pellitero 1992, 1993a,b). Lom \& Dyková (1988) reported that the junction of shell valves of $K$. lunata was oblique. In $K$. paralichthys, the junctions of shell valves were not oblique but L-shaped.

Acknowledgements. This work was supported by grant no. R01-2000-000-00215-0 from the Basic Research Program of the Korea Science and Engineering Foundation.

\section{LITERATURE CITED}

Dyková I, Lom J, Overstreet RM (1994) Myxosporean parasites of the genus Kudoa Meglitsch, 1947 from some Gulf of Mexico fishes: description of two new species and notes on their ultrastructure. Eur J Protistol 30:316-323

Langdon JS (1990) Observations on new Myxobolus species and Kudoa species infecting the nervous system of Australian fishes. J Appl Ichthyol 6:107-116

Lom J, Arthur JR (1989) A guideline for preparation of species descriptions in Myxosporea. J Fish Dis 12:151-156

Lom J, Dyková I (1988) Sporogenesis and spore structure in Kudoa lunata (Myxosporea, Multivalvulida). Parasitol Res 74:521-530

Lom J, Dyková I (1992) Protozoan parasites of fishes. Elsevier Science Publishers, Amsterdam

Lom J, Dyková I (1996) Notes on the ultrastructure of two myxosporean (Myxozoa) species, Zschokkella pleomorpha and Ortholinea fluviatilis. Folia Parasitol 43:189-202

Moran JDW, Whitaker DJ, Kent ML (1999) A review of the myxosporean genus Kudoa Meglitsch, 1947, and its impact on the international aquaculture industry and commercial fisheries. Aquaculture 172:163-196

Narasimhamurti CC, Kalavati C (1979) Kudoa tetraspora n. sp. (Myxosporidea: Protozoa) parasitic in the brain tissue of Mugil cephalus. Proc Indian Acad Sci 88B:85-89

Pampoulie C, Marques A, Rosecchi E, Crivelli AJ, Bouchereau JL (1999) A new myxosporean parasite, Kudoa camarguensis n. sp., recorded on two goby species (Teleostei: Pisces) in the Rhône Delta (Mediterranean Sea, 
France). J Eukaryot Microbiol 46:304-310

Paperna I, Zwerner DE (1974) Kudoa cerebralis sp. n. (Myxosporidea, Chloromyxidae) from the striped bass, Morone saxatilis (Walbaum). J Protozool 21:15-19

Sitja-Bobadilla A, Alvarez-Pelitero P (1992) Light and electron microscopical description of Sphaerospora dicentrarchi n. sp. (Myxosporea: Sphaerosporidae) from wild and cultured sea bass, Dicentrarchus labrax (L.). J Protozool 39:273-281

Sitja-Bobadilla A, Alvarez-Pelitero P (1993a) Ultrastructural and cytochemical observations on the sporogenesis of Sphaerospora testicularis (Protozoa: Myxosporea) from Mediterranean sea bass Dicentrarchus labrax (L.). Eur J Protistol 29:219-229

Editorial responsibility: Wolfgang Körting,

Hannover, Germany
Sitja-Bobadilla A, Alvarez-Pelitero P (1993b) Light and electron microscopical description of Ceratomyxa labracis n. sp. and a redescription of C. diplodae (Myxosporea: Bivalvulida) from wild and cultured Mediterranean sea bass Dicentrarchus labrax (L.) (Teleostei: Serranidae). Syst Parasitol 26:215-223

Stehr C (1986) Sporogenesis of the myxosporean Kudoa paniformis Kabata and Whitaker, 1981 infecting the muscle of the Pacific whiting Merlucius productus (Ayres). J Fish Dis 9:493-504

Swearer SE, Robertson DR (1999) Life history, pathology, and description of Kudoa ovivora n. sp. (Myxozoa, Myxosporea): an ovarian parasite of Caribbean labroid fishes. J Parasitol 85:337-353

Submitted: November 19, 2002; Accepted: February 10, 2003 Proofs received from author(s): June 2, 2003 